\title{
Impact of Intensive Training and Quality Assessment on Core Competency of Oil And Gas Employees in Yemen Petroleum Companies Fall Under Competency Framework
}

\author{
Ahmed AL-Qadhi, Abdulaziz Abdullah
}

To Link this Article: http://dx.doi.org/10.6007/IJARBSS/v11-i4/9719

DOI:10.6007/IJARBSS/v11-i4/9719

Received: 10 February 2021, Revised: 13 March 2021, Accepted: 25 March 2021

Published Online: 15 April 2021

In-Text Citation: (AL-Qadhi \& Abdullah, 2021)

To Cite this Article: AL-Qadhi, A., \& Abdullah, A. (2021). Impact of Intensive Training and Quality Assessment on Core Competency of Oil And Gas Employees in Yemen Petroleum Companies Fall Under Competency Framework. International Journal of Academic Research in Business and Social Sciences, 11(4), 750-770.

\section{Copyright: (c) 2021 The Author(s)}

Published by Human Resource Management Academic Research Society (www.hrmars.com)

This article is published under the Creative Commons Attribution (CC BY 4.0) license. Anyone may reproduce, distribute, translate and create derivative works of this article (for both commercial and non-commercial purposes), subject to full attribution to the original publication and authors. The full terms of this license may be seen at: http://creativecommons.org/licences/by/4.0/legalcode

Vol. 11, No. 4, 2021, Pg. 750 - 770

Full Terms \& Conditions of access and use can be found at http://hrmars.com/index.php/pages/detail/publication-ethics 


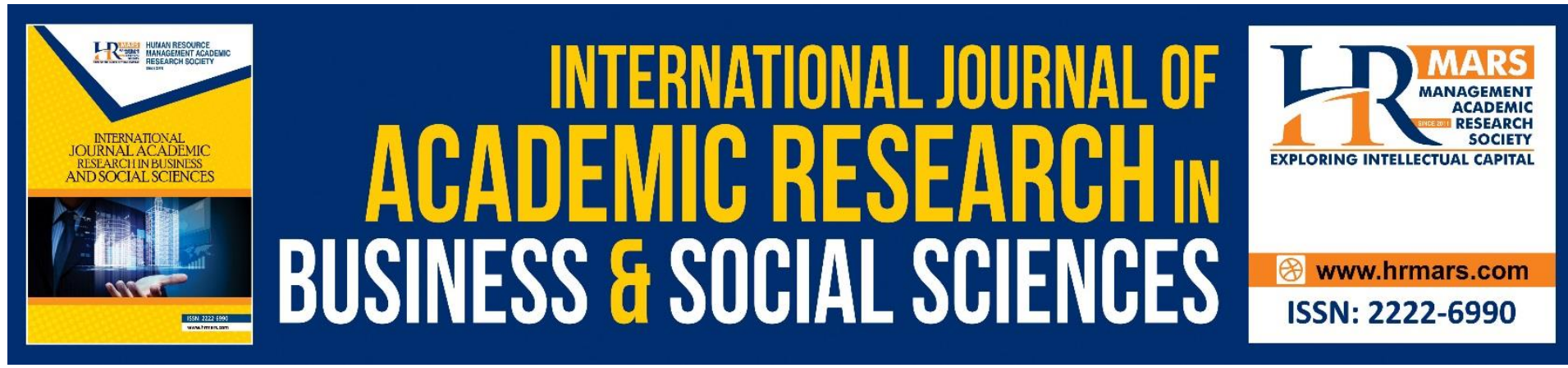

\title{
Impact of Intensive Training and Quality Assessment on Core Competency of Oil And Gas Employees in Yemen Petroleum Companies Fall Under Competency Framework
}

\author{
Ahmed AL-Qadhi, Dr. Prof. Abdulaziz Abdullah \\ University Sultan Zainal Abidin, Malaysia
}

\begin{abstract}
The Competency model is vitally essential for the protection of petroleum companies workforce during operations, commissioning, shutdown, troubleshooting, maintenance and any lack of the core competencies of employees would lead to production interruption, damage assets, environments and company reputation, likewise this research focused on several aspects including intensive training, quality assessment to identify the core competency level in term of competency model, wherefore purposive sample was employed and 350 technical employees from operation, maintenance, and safety division ,meanwhile qualitative and quantitative study conducted among expertise and oil and gas employees, and collected data analyzed and interpreted by statistical methods (SPSS and SEM ). The result of data interpretation provides affirmation of significant positive effect of intensive training on employees' core competence with limited specific gaps in safety issues and troubleshooting and recommending action plan to bridge such gaps. The impact of this factor resulted into $60 \%$ of core competency success
\end{abstract}

Keyword: Intensive Training, Quality Assessment, Competency Models; International Petroleum Companies, Core Competence, Safety

\section{Introduction}

The significance of the competency model, integrated with the identification gaps has been improved since the year 2000 by understanding and abilities of the wide hydrocarbon industries. Similarly, the priority of O\&G managers and employees to be competent and productive can be achieved by a competency-based development program, which understands and meets its particular task criteria for each position (Connor et al., 2014). Intensive training and quality assessment are typically based on competency approaches to identify various abilities, methods, attitudes, and knowledge gaps for effective processing. The competency model concentrates on functional and technical needs with immense courtesy of skills and knowledge required in performing a particular job (J. Connor, Mark, Casey, Karen, Eddon, , 2014) However, the smooth running of a factory requires professional abilities that can only be attained in long-term employment. According to (P. D. Walker, 
Cammy, Ellis, \& Seibert, 2011), the lack of operational abilities can restrict the plant's efficiency. (Sugarindra, Suryoputro, \& Novitasari, 2017) highlighted the gap in the identification of workplace hazards resulting in accidents and their main causes including the absence of understanding and abilities during new technology processing. Additionally, compliance with health, safety and environment (HSE) instructions and regulations is an important component in the mitigating or removal of accidents; because otherwise, staff refers to events in the absence of attention to security processes, hence risk evaluation plays a crucial role in the HSE system (Aven, 2016).

Organizational deficiencies and skills gaps in plant operations have affected the O\&G sector in the Yemen republic. The absence of long-term strategic planning to reduce deficiencies led to the instability of the Business World (WorldBank, 2015) Yemen has less than $50 \%$ of its complete human capital potential in the World Economic Forum, which measures the gaps in the nation's economies and optimizing their potential as human capital through schooling and skills development World Economic (Leopold, Ratcheva, \& Zahidi, 2017). According to Gannah Hunt's operations engineer, stated that troubleshooting, plant shutdown, human errors, damaged properties, and presence of a gap in knowledge, skills, and behavior among Yemeni operators and technicians are the root causes of inadequate training and evaluation (Ali et al., 2020)

In the recent conferences of Chevron's industry specialists and the University of Houston Energy, preparing future leaders in the energy sector has been discussed. John Colborn, director of "Skills for America's Future, found discontinuation among higher education institutions and businesses. He revealed that while the university students consider that they are fully prepared for the job, the employees would say no (Jones|, 2015) . Therefore, intensive training represent in field technical training, health, safety and environment training, advance specific training, and quality assessment in stages is required to meet international standard of oil and gas companies

\section{Components in Major Oil Companies}

The competency factors outcomes of literature and industries are summarized in Table 1. The selection of most variables or factors has been made to construct a theoretical, conceptual model and achieve the current study's objectives. With the selection of intensive training, quality assessment, and motivation in attaining competent operators and technicians, I ran a preliminary study to justify selecting the above constructs,

Table: 1. demonstrates the essential components of the competency framework in international major O\&G companies globally. Almost all oil companies have a comparative framework related to training and assessment. However, they are distinguished in some aspects, including the training program, management policy regarding disciplinary action against failed trainees, assessment way, gap processing or treatment, career management, reporting, and computer software. 
Table 1. Critical components in major oil companies

Competency Components Companies Reference

Competency Intelligence Solution

(Matteo, 2019)

Gaps define

Training Development Plan

Capability Assessment Method

On job Practice

Management Reporting

Competency Assurance Management System

(Almatroushi, 2006)

Training

Basic training

On-the-job training

Personal development plan PDP

Gate assessment (4),

Competency Development Framework $\quad$ (J. Connor, 2014)

Process standardization

Self/supervisor assessment

Verification process

Identify the gap

Competency content program

Learning and development

Application in the field

Gap analysis and planning

Strategic Competency Management

(Kedzierski, 2016)

Competency assurance

Identifying risk

Position

Task and role

Training

Assessment

Learning Management System (LMS)

Training needs analysis and evaluation.

(McKinley \& Huebner,

Development and delivery of instructor-led training courses 2018)

Process safety training solutions

Personnel develop skills

Experiential setting

Assessment

Petronas Competency-Based Assessment System (PECAS)

Standard

(Hashim, Ahmad, \&

Assessment, Rohiza, 2010)

Quality assurance

Certification 


\author{
Competency-Based People Strategy \\ Recruitment and selection \\ Performance management \\ Career management \\ Reward management \\ Training and development \\ (McKinley \& Huebner, \\ 2018)
}

\section{Competency Development}

Recruitment and selection

Induction

Foundation

Technical training

Workplace learning
(Al-Marri, Al-Habaibeh, \&

Watkins, 2018)

\section{Intensive Training}

The first selected component was intensive training, which addresses the challenges the O\&G companies faced, providing suitable matching for industry requirements (Rui et al., 2018). Employees' knowledge, skill, behavior, and experience are significant elements in advancing a high performance/high skill workforce to face challenges in risky operations (Figgis \& Standen, 2005). (Figgis \& Standen, 2005) pointed out that adhering to safety, health, and environment, delivering questions, and aspiration in learning is a decent landmark in behavior essential for O\&G organizations (Figgis \& Standen, 2005). Alternatively, they plan an effective training program based on initial assessments in identifying gaps and weaknesses and designing a training program for each role and position also important for O\&G companies (P. D. Walker et al., 2011). The essential factor in the competency model is training, which should be aligned with trainees' needs and effectively interact with the training program. These practical trainings are efficiently suitable in gaining knowledge, skills, behavior, and experience as they are linked with the existing experience of employees and coach supervision (Matteo, 2019).

However, the best topics for trainees are related to risks and safety issues, plant troubleshooting, start-up/shutdown activities, and emergency events, while the literature review did not adequately discuss this issue (Williams \& Turnbull, 2015). Although technical training focuses on risk assessment and risk management to control accidents to extent limits, yet unsafe acts are risen by technicians (Al-Awai, Samir, \& Binthabet, 2002; Capp, Lazarewicz, \& Rojas, 2010). The priority of O\&G companies is safety, sustainability, assets' observation, and employee protection. Therefore, the O\&G companies designed a competency model to achieve the abovementioned goals (Blanchard, 2006). According to (P. Lee, Allen, \& Daly, 2012), safety awareness is a priority in the petroleum industry. (Sahinidis \& Bouris, 2008) conducted a study that linked the employee's competency and attitude with the training received. They claimed a significant relationship between the employees' competence and commitment, job satisfaction, and motivation.

Alternatively, the training program objectives should be linked with the class's learning process and on-job practices in the field (Tello Rueda, 2006). To induce practical training, (Schmidt, 2007) suggested the following essential steps;

a. Finding out the current competency level of employees. 
b. Conducting an initial assessment to identify the gaps.

c. Identifying the required competency level for a particular position.

d. Setting out the appropriate training and personnel development program.

e. Assessing within the training cycle.

f. Final assessment

g. Verification and integration

h. Gap identification

The above steps are necessary to meet trainees' requirements to ensure employee competency and incorporate them into the work (Antariksa, 2009). Conversely, the initial assessment is a critical factor in gap identification before the start of the training program intended to meet the training program's commencement 2011). (Fassihi, 2005) claimed that competency-based training plays a vital role in perceived competence differs from traditional training. Based on this theory, material and extensive hours as course requirements prepared by internal coach, decreasing the role of competency approach resulting in commonality useful material (Fassihi, 2005). Likewise, (Figgis \& Standen, 2005) proved that training-based on the competency system produces professional workers in the world's real sense. Hence, conventional training does not satisfy the employees to gain cognitive knowledge, practical skills, attitude, and experience (Abder \& Thomas, 2003). Consequently, core competency is the goal to which training and development are aligned.

Concerns have been raised by Finegold et al. (1988) that competency-based training is needed to meet the industrialized economy. Similarly, lacking skilled employees adversely influences economic development (Finegold \& Soskice, 1988). Therefore, the O\&G organizations set out appropriate plans to clear this concern, create the competency assurance management system, and recruit experts in specific fields, including leadership, skill management staff, an expert in competency system (Andersen \& Mostue, 2012). Because of the high risks in the $O \& G$ industry, curiosity developed to avoid or mitigate them to the minimum limit. Therefore, a competency system has been constructed to prepare competent employees to face the challenges of safety issues and achieve organizational targets (Figgis \& Standen, 2005). However, (Andersen \& Mostue, 2012) paid attention to developing a flexibility-based model in operational risk to promote the hazard management process. Therefore, training should focus on the risk associated with the work area. The main goal of training is to achieve core competence (Abder \& Thomas, 2003), which justifies why training is vital in structuring a competency model. The International Human Resources Development Corporation (IHRDC) set out a learning and development plan, where employees are evaluated to identify the gaps and develop a learning plan to fill the gaps to meet the contenders' needs (Naburi, 2014). While selecting the approach required for new abilities, more profound technology, staff training should be high on the organization's action agenda (Vathanophas, 2007). However, (Schmidt, 2007) manifested that a competency-based training program for fresh graduates has been started with familiarization of employees' current competency level to identify a gap and set the training development program and assessment process (Wang, 2018). A suitable training program and personal development plan significantly influence core competence (Farr, Hofmann, \& Ringenbach, 1993), justifying the selection of intensive training in organizational attempts to create skill-based competence (Vathanophas \& Liang, 2007). 


\section{Basic Technical Training}

According to competency specialists in the oil and gas fields, technical training incorporates the plant's classroom and practices (Al-Awai et al., 2002; Almatroushi, 2006; Koç, 2017). Based on literature related to technical training in $O \& G$ companies, the class training is significant in knowledge acquisition and skills needed before moving to on-job training in the plant (Almatroushi, 2006; Arneson, Rothwell, \& Naughton, 2013; Naburi, 2014). The contents and material prepared to deliver in the class and on-job tasks should meet the organization's requirements (Bosch \& Charest, 2009). According to (W. J. Rothwell, Graber, James M,Graber, Jim $M, 2010)$, competency-based training maximizes the performance level among employees. It has been shown that the necessary technical training phase enables fresh employees to realize and identify the process's different features. Although, through the competency model, trainees acknowledge their requirements and practice (Lucia \& Lepsinger, 1999), an effective training program can also be negatively affected by the repetition of the contents (S. H. Lee \& Ming, 1999).

The training program's total duration depends on the developer how swiftly he can match a personal development program (PDP) (Al-Awai et al., 2002; Jarossová, 2018; Saadawi \& Al Olama, 2005). Some companies take $2-5$ years to join the team and carry full responsibility during work without supervision (Almatroushi, 2006; Naburi, 2014; Tarrant et al., 2014). An important subject related to basic technical training in O\&G companies is job-related safety and health. Safety, health, and environments are the priority in the O\&G industry (Henley, Pinheiro, \& Daly, 2011). Several studies have recommended that knowledge acquisition and skills be near behavioral shift and productivity (Rouiller, Capt, Dolivo, \& De Ribaupierre, 1989; Rouiller \& Goldstein, 1993; Xiao, 1996). The trainees' feedback toward the training program helps update and improve the program (Al-Awai et al., 2002; Almatroushi, 2006; Koç, 2017). According to (Alvarez, Salas, \& Garofano, 2004), a training program's design reflects the essential objectives of the personal development plan where the content structure and the material are used (Abdullah \& Suring, 2011). Improper training design can result in the unfertile transfer of training, as trainees would not have gained proper knowledge and skill (Holton III, Bates, \& Ruona, 2000; Yasin \& Ali, 2016). Recent literature has recommended a design program that matches the trainee job with practical exercises and a similar environment, which will help improve the learning process (Rodríguez \& Gregory, 2005). However, as part of the competency design, the content should be straightforward and easy to understand (Tello Rueda, 2006). (Gegenfurtner, 2011) noted that trainees' satisfaction toward training content enhances motivation, resulting in increased training conveyance. Therefore, to boost motivation in a training program, it should be relevant to the trainees' job tasks (Gegenfurtner, 2011).

\section{On-Job training (OJT)}

On-the-job training (OJT) is a field practice, in which trainees' knowledge acquisition in the class should be fit with the workplace (Al-Awai et al., 2002). Trainees learn activities from the trainers and managers through thoroughly observing their work (Saeed et al., 2013). Supervision and practical training by skilled pool experts contribute direct support to the workers (Matteo, 2019), justifying the importance of job practice on core competence in the competency model. According to (Noe, Hollenbeck, Gerhart, \& Wright, 2017b), OJT is a standard training method, which should not be a part of the training approach, regardless of 
its positive impacts. Alternatively, (Anane, 2013) stated that on-job training is a useful method that can improve employees' job performance and competence more than lectures.

The Illinois Department of Human Services (Matteo, 2019) points out those OJT activities should be matched with competencies key components attained in the schoolroom. The OJT program is an efficient way to change unemployment into employment and provides accessible abilities and a cost-effective means to local businesses to grow and maintain the workers they needed (Van Haitsma et al., 2018). OJT is a productive means for employees, enabling them to improve their abilities they needed in real work conditions (Jargons, 2018). Absenteeism of OJT negatively affects employees' core competence, leading to production disruption, damage of assets, and the environment (Holton III et al., 2000; Yasin \& Ali, 2016). According to the literature relevant to ADNOC petroleum companies, the developers are welleducated about the job description, equipment function, permit to work system, process flow diagram (PFD), a process instrumentation diagram (PID) troubleshooting, emergency response, risks and hazards of plant, firefighting, control system, day-to-day activities, logbook, and drill activities (Al-Awai et al., 2002; Matteo, 2019; Saadawi \& Al Olama, 2005). One of the essential technical training elements is focusing on risks during the initial startup/shutdown of the factory, malfunction of equipment, control system, permit to work system, and emergency conditions. Consequently, the theoretical and practical training on risk assessment and management is essential in raising the employee's competence (Al-Awai et al., 2002; Capp et al., 2010; Wang, 2018). Additionally, the e-learning system, simulator, videos, external short courses, skills, conducts, and experiences are essential to achieve core competence (Naburi, 2014). According to (Warwick, 2014), e-learning training supports the individual who searches for gaining knowledge and skills, rather than show off (Wilson, 2015). Therefore, training support is a tool that enables the trainees to understand the subject effortlessly and perform their tasks proficiently (Walker et al., 2011).

\section{Advance Training}

Advance training is introduced to best performance operators and technician, who show credibility, and reliability, covering all material in efficient manner, and recommended by all staff of skill pool expert, so he nominated for special training in DCS, troubleshooting, vendor training inside and outside, Hazop training, operation procedures, emergency cases, simulator training, if he achieve the advance training and assessment process efficiently, he promoted to high position, the committee of skill pool expert with management recommended him to high position, (Exon Mobile). However the advance training could be last for 5 years, depend of KPI (key performance indicator who issued monthly by skill pool expert, (Exxon Mobile).

The advance training material

The practical training program has been demonstrated in Figure 1. 


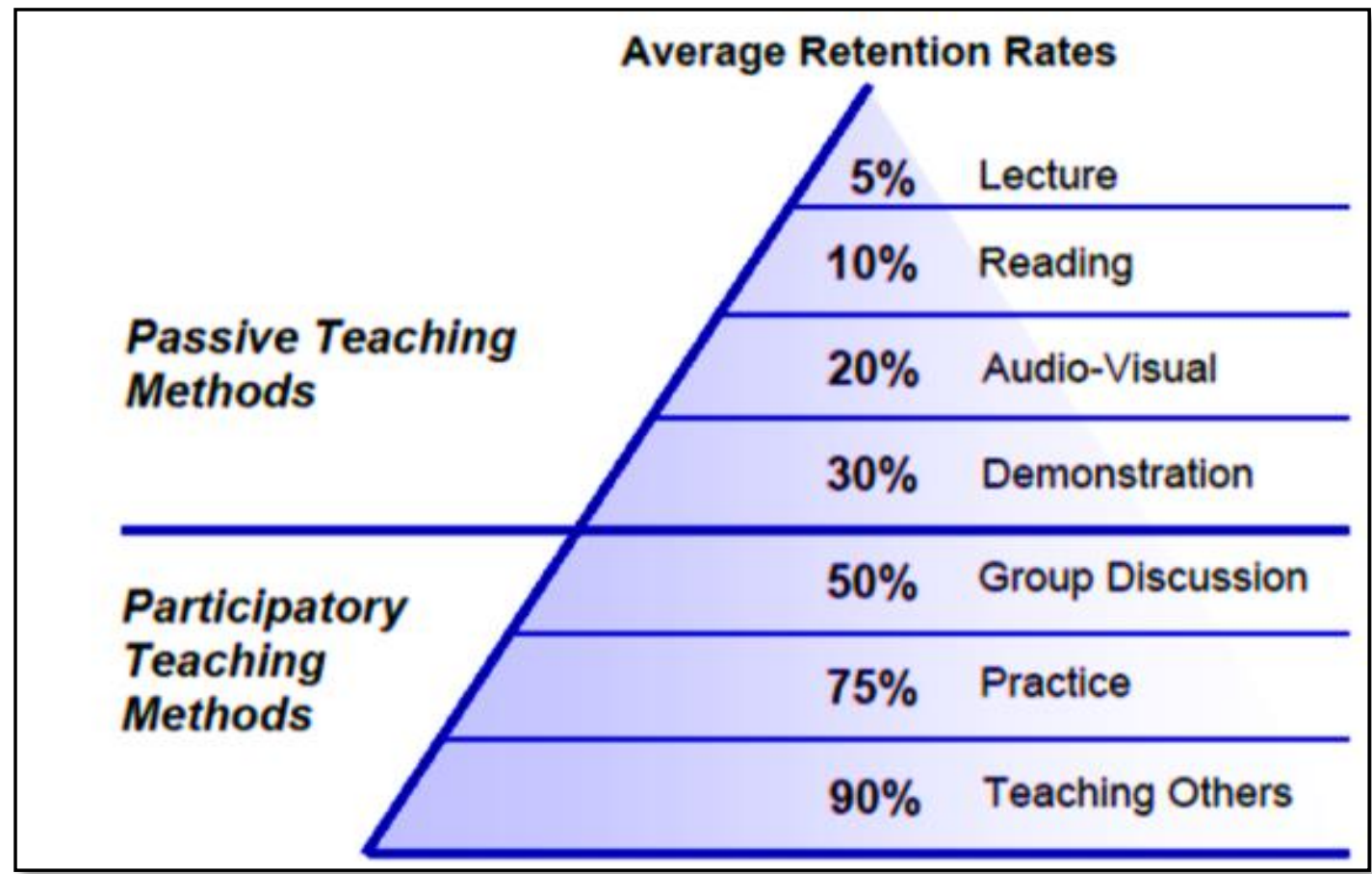

Figure 1. Effective training program (P. D. Walker et al., 2011)

\section{Personal Development Plan (PDP)}

The personal development plan (PDP) is a mandatory process to develop the employees' careers through various learning programs (Al-Awai et al., 2002). The PDP is useful for career development as its contents and material are specified (Tello Rueda, 2006). (Alipour, Salehi, \& Shahnavaz, 2009) stated that the preparation of the quality-training material is a core factor in the success of PDP improved worker's competence (Orser, 2001). According to, (James L. Farr, 1993) PDP influences the candidates' performance involving soft skills courses, including communication skills, interpersonal skills, leadership, effective involvement, decision-maker, critical thinking, and fair criticism (Walker, Cammy, Ellis, Seibert, Kelly, 2011). These short courses enhance individuals' morale and encourage the employees to attain core competence (He, 2019) have demonstrated that PDPs should focus on specific works' tasks and device efficient tools to determine the progress. Thus, works' tasks determined by PDP should be completed by the trainee before integration into the established post (Samir, 2002). According to various literature, gaining knowledge, skills, and behavior involves an effective training program to meet training requirements after gap identification. This assurance employee's involvement and job security, which results in higher performance and sustainability, company's productivity, and profitability,

\section{Interpersonal Skills}

Interpersonal skills of trainees are the essential factors of a personal development plan that enhances the behavior and techniques used by an individual to connect virtually with others. Common examples of interpersonal skills are active listening, teamwork, responsibility, dependability, leadership flexibility. The interpersonal courses provide an intermittent period from the start of the training program to the end of the program within 2-5 years, depending on HR policy (Walker et al., 2011). The interpersonal courses motivate the trainees to achieve their organizational goals and acquire core competence (Fassihi, 2005).

Effective Communication Skill 
(Hamza \& Hahn, 2012) stated that useful communication skill in delivering training material is a significant factor in developing a practical training vision or mission and considered one of the main tools in the training's success. There are three tips for practical communication skills, including building trust with participants through effective engagement, covering the whole subject efficiently, and giving significant attention to a participant question. In training, communication skill is a significant element to cover the entire subject, building trust, and pay attention to participants (Hamza \& Hahn, 2012).

\section{Relevant Theoretical of Proposed Competency Development Framework}

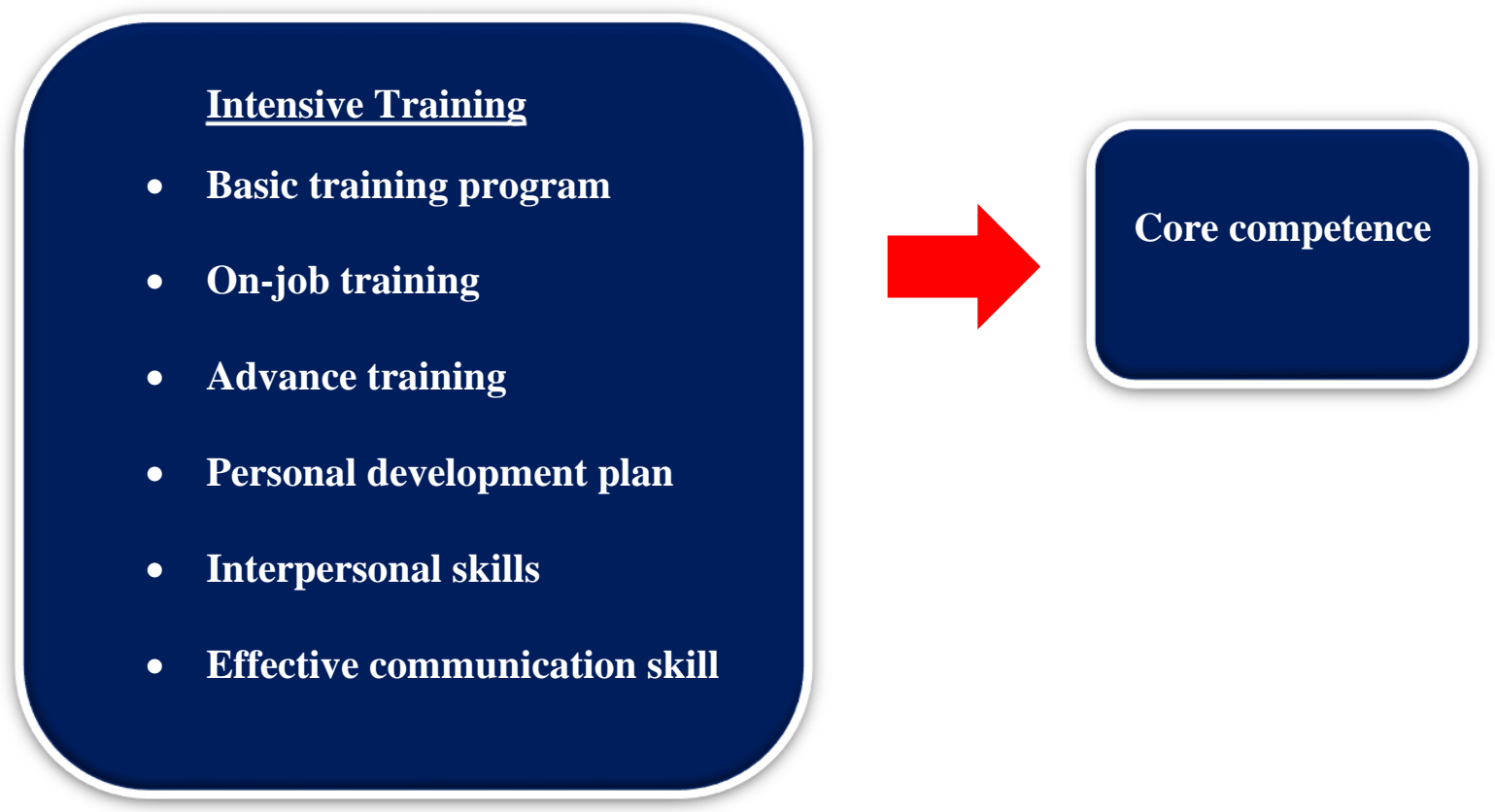

Figure 2. Intensive training related to competent employee Quality Assessment

The recent literature defines the assessment as a regular assessment process and recording employee's performance against work (Lawler, 1984) According to (Rothwell et al., 2010), addressing staff assessment in their organizations and all agreed with the competency model's assessment significance is to identify the gaps requirements and set out the optimum training program. Positive or negative performance assessment feedback is essential for employees to improve their level (Pulakos, Mueller-Hanson, \& O'Leary, 2008). However, performance evaluation is a continuous process to ensure individual competence (Rothwell et al., 2010). The essential elements of assessments at the early stage of training to identify the gaps in knowledge, skills, and behavior can emerge as the trainee progresses through his competency development program (Samir, 2002). However, once employees learn new skills and apply them to the job, they reviewed to ensure that gaps are filled, updating their competency profiles to fill the gaps (Naburi, 2014). One criticism of quality assessment has been manifested by (Pignot-Shahov, 2012) tolerance, range of information, radiance appearance impact, lack of experience, and discrimination lead to inadequate assessment or failure of appraisal, which is also known as Psychometric errors (Appelbaum et al., 2013). However, other researchers emphasize that self-performance appraisal is another tool that can help and support the multi-rater scheme to decrease psychometric errors. 


\section{Assessment of Competence}

Assessment is made of the trainee's performance for each process he/she has been trained in. The skilled pool expert will use the activity reports completed by the trainee in making a decision. The assessor can meet the trainee who operates the process along with reviewing the activity reports. For each assessment, the trainee should record the evidence in which he/she agrees with the assessor to be brought forward. This evidence should be listed in a register of supporting evidence assessment results recorded on the checklist. Similarly, in every case, the assessor should complete a feedback report (Karami, 2020). The trainees should understand how the process is performed. Both trainees and assessors should use this document to ensure no gap has been left in employees' competency.

Before signing any assessment checklist sheets, the assessor should be confident that the trainee has proved himself in the operation of the process and all the standards and supporting knowledge requirements within various components. Assessment of competence should be done by direct observation, and evidence should be used to approve the assessment process/decision (Karami, 2020). Additional evidence sources will be as follows;

a) Written evidence in the form of activity reports.

b) It is supporting evidence in the form of additional documentation.

c) Direct questioning of the trainee to ensure that he/she has a sufficient understanding of the process and its supporting principles.

d) Witness statements from experienced and competent work colleagues.

Once the assessor is satisfied with the candidate's evidence and confirms his/her competence standards, and knowledge, then signs the appropriate sections. 


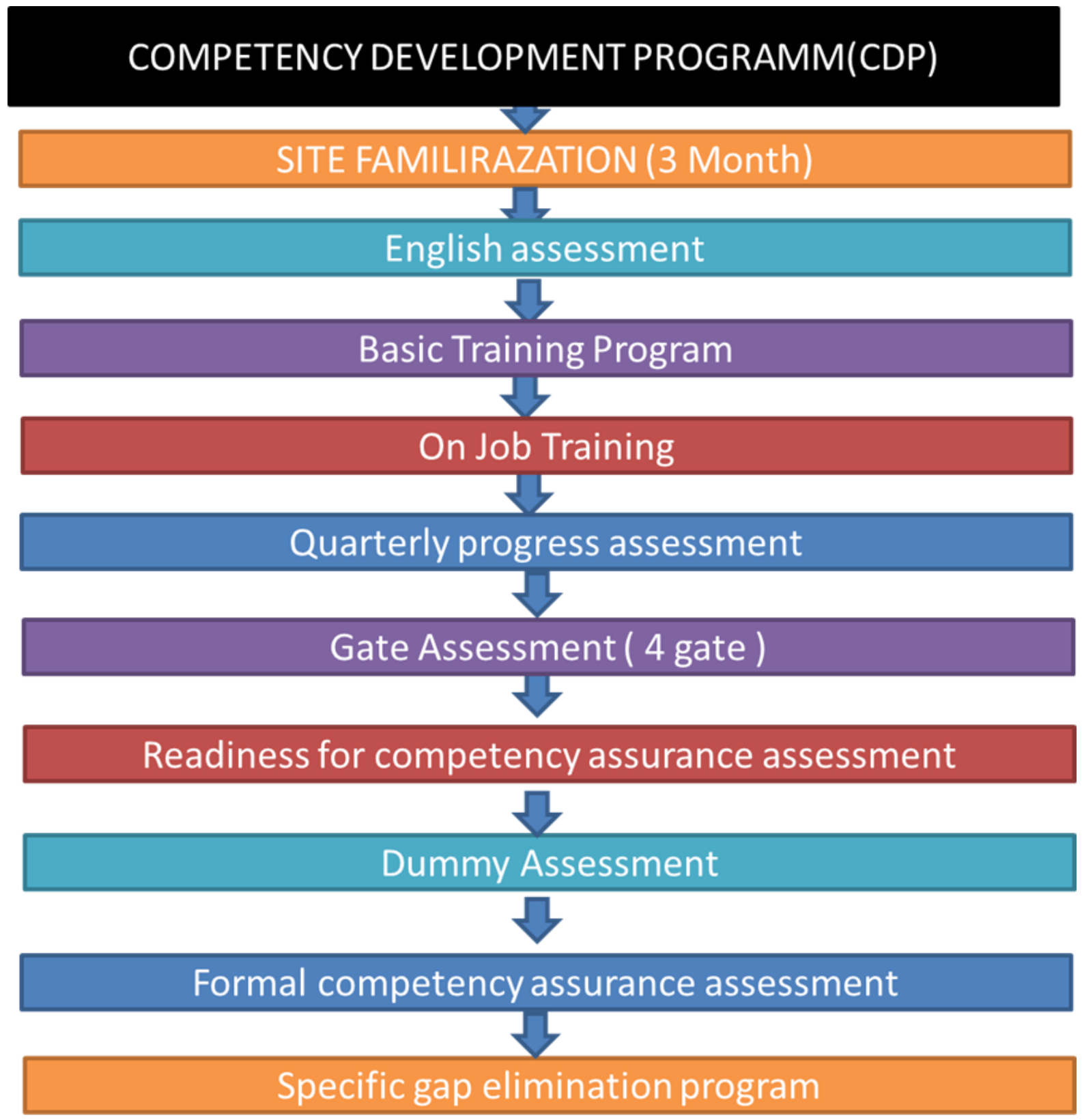

Figure 3. Assessment Checklist

\section{Register of Supporting Evidence}

The following document should be used to compile a register of all evidence you wish the assessor to consider in support of your competence. These shreds of evidence include work permits, authorization, written procedures, and code of practice, schedules, and other relevant documents. Copies of supporting evidence documentation should be included in the relevant sections of the 'logbook.' The originals of all such evidence should be stored at the location indicated by the location on your register (Appendix. 3 ).

\section{Knowledge Assessment Checklist}

In addition to attaining competence in the various processes' tasks, the trainee working with the competency, the team should be satisfied that he understands the principles that support 
them. The competency expert team should assess knowledge in certain key areas across the standards. He should achieve the following knowledge items, and check each candidate's performance after demonstrating full competence in that area (Appendix 4, Appendix 5). Through the training and assessment process, the trainees know the point of strength or weakness and level of required performance-critical even through a competency management model designed for tracking the employees' development progress level ( Rothwell et al., 2010). According to (Perry, 2006) the personal development training program's strengths and weaknesses can be evaluated as planned objectives for updating the confidence rate (Warner, 2009). According to previous literature, inadequate assessment refers to the employer's aim rather than employees' needs (Bates, 2014).The literature points out that the assessment method is all-inclusive and should cover all competency-based training assignments (Al Matroushi, 2004)

An accurate assessment is a function of a competency framework that measures all significant dimensions of the program (Leuro \& Kruger, 2014). The skilled pool expert offers trainees generous support to overcome any difficulties. According to the competency program, the trainee-supporting tools include an e-learning system, CBT, a simulation system, and external training (Saadawi \& Al Olama, 2005)

\section{Performance Criteria}

Performance-based competency standards are used to enhance the training and development of a competent coach (Lo, Macky, \& Pio, 2015). The aptitude of each element's performance level can be expressed in its four levels, including awareness, knowledge, skill, and mastery. Measuring competencies is a critical element of evaluating the trainees' performance to define the job specification and determine the required competencies. According to (Howland \& Moore, 2002) competency can be measured in terms of awareness, knowledge, skill, and mastery. Thus, the performance estimation is a reply to any queries related to the required assignments, which evaluate the trainee's levels .(Borch \& Kjerstad, 2018)

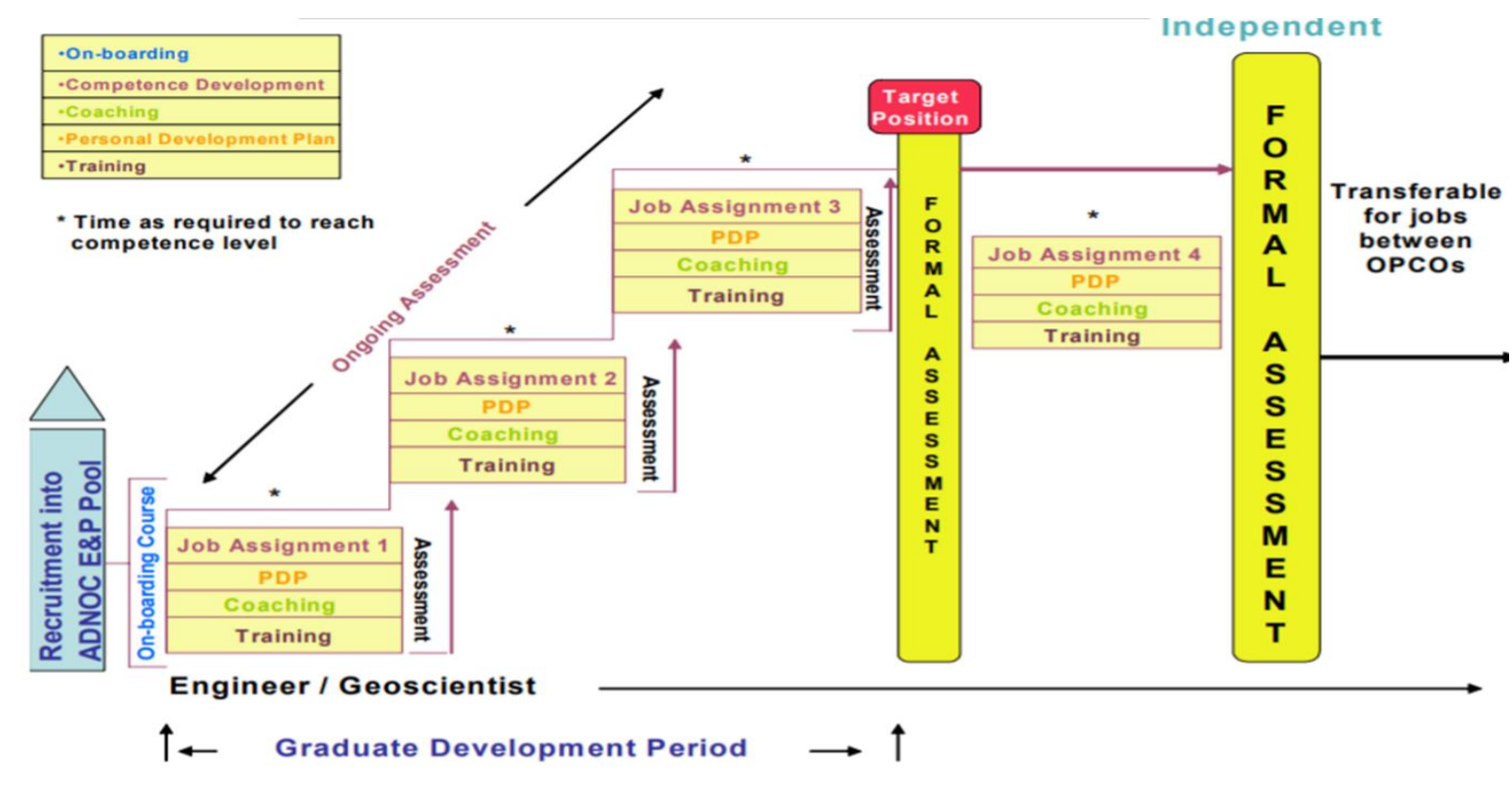

Figure 4: Training and assessment method (Almatroushi, 2006) 


\section{Competence Software (CS)}

Recently, most of the companies assessed internet-based competence software, which is designed to meet the needs of the O\&G industry. Alternatively, the old assessment methods are typically paper tests using pen and interviews (Pulakos et al., 2008). Referring to the recent literature, assessment quality is a vital tool to control various activities, including managing workforce competency, audits, monitoring performances, operating activities, training evaluation, and E-learning management .Naburi (2014) Omar, Al Hosani, \& Moore (2008)

\section{Dummy Assessment (DS)}

Although (Omar et al., 2008) conduct dummy assessments one-month before the official competency assurance (CA) verification, DS's primary purpose is to prepare the trainee for the final verification test. The assessment is conducted by the discipline instructor and line supervisor relevant to the post-job audit form (PJAF) (Samir, 2002). The dummy assessment has roughly the same questions in the content as given by an external verifier. The questions cover the contents of both essential pieces of training and OJT tasks. The simulated assessment evaluates technical ability and knowledge and simulates the atmosphere for actual assessment with the external verifier

\section{Final Assessment}

The final assessment is a scale for trainee future; to join an organization or go back home (Howland \& Moore, 2002) noted that final assessment is a decisive step since it is correlated with the required core competency of the personal development program, covering the last stage of the training cycle including troubleshooting, start-up/shut down activities, emergency events, safety, fire, equipment malfunctioning. The final assessment is conducted before external verification in which the future work of the trainee is determined (Bain et al., 2019). As claimed by competency experts, employee competence comes under crucial performance indicators (Rothwell, Arneson, \& Naughton, 2013) noted that the employee's competence is estimated against organizations' implementation principles. Nevertheless, various estimates should be considered while implementing the competency model.

\section{Verification Process}

The verification process (VP) is intended to verify the quality assurance of the candidates' knowledge acquisition and skills aligned with international authorities of accreditation and certification (Almatroushi, 2006; Naburi, 2014). The internal verifier (IV) and external verifier (EV), who monitor consistency and quality assessment activities, conduct the verification process. In qualitative assessment, IVs' primary responsibility is how the assessment activities are applied in the sector related to the EV's satisfaction. Most of the companies performing the verification process (IV, EV) should be accredited and integrated into the plant. The IVs should know and experience in the facilities (Almatroushi, 2006) (Naburi, 2014)

\section{Specific Gap Elimination Program}

It has been demonstrated that knowledge gaps during the assessment were cleared proved where trainees had not explained particular tasks, as they did not get a chance when they were being supervised (Taber \& McGarr, 2013). According to a competency specialist, as long as a competency gap is determined after the essential evaluation, the employee should be offered assessment and reappraisal chances. Chances for evolution include on-job 
experience, schoolroom coaching, application, computer-based framework, and handson/simulator actions. A policy and timeline for appraising the employee should be documented (Almatroushi, 2006). Upon completion of IDP/CA campaigns, each candidate identified gaps scored less than $100 \%$, converted into a program known as the Specific Gap Elimination Program (SGEP), which has a period and responsibilities gap elimination.

\section{Relevant Theoretical of Proposed Competency Development Model}

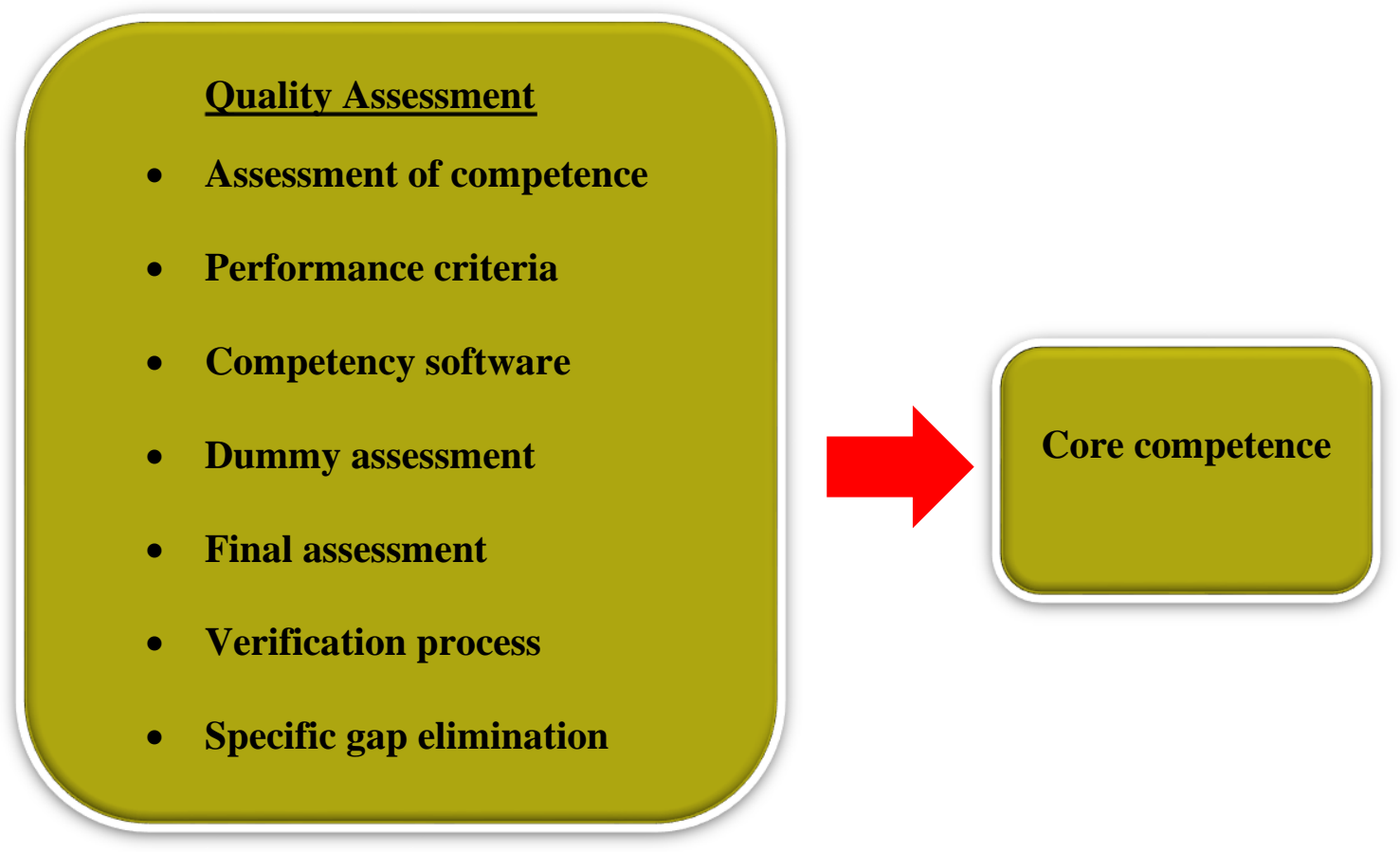

Figure 5. Relationship of quality assessment and competent employee

\section{Benefits to Yemeni Workers}

Employees know the standards expected of them and their achievements, training are recorded, and recognised, in addition their performance can be compared to KPI of international companies(Al-Awai, 2002)

The employees achieve a sense of security in running the job, and improve moral emanating from sense competency and recognition of that competency by their supervisors and peers (Almatroushi, 2006; Noe et al., 2017a)

\section{Finding}

The summary of the regression results shows that four sub-dimensions of intensive training, quality assessment, motivation, and skill pool expert explained 23.9 percent of the variance in the dependent variable (core competence), but the results of the ANOVA analysis to test the significance of the regression show that the value of significant is zero, which is less than 0.01 . As a result, the null hypothesis is dismissed and the alternative hypothesis is accepted; so the independent variables have an effect on the dependent variable, even if the independent variable can estimate the dependent variable, on the other hand, the coefficient analysis reveals that intensive training $[b=0.042, t=0.588, p 0.05]$ and motivation $[b=0.570$, $t=9.601, p 0.05]$ have important effects on core competences, according to the coefficient study. However, several dimensions, such as quality assessment [ $b=0.055, t=0.734, p>0.05]$ and skill pool expert $[b=0.079, t=1.044, p 0.05]$, showed no correlation with core competence. 
Table 3. Multiple Regression Result

\begin{tabular}{|c|c|c|c|c|c|c|c|c|}
\hline $\begin{array}{l}\text { Dependent } \\
\text { Factor }\end{array}$ & Independent & $\mathbf{R}$ & $\begin{array}{l}\mathbf{R} \\
\text { Square }\end{array}$ & $\mathbf{F}$ & $\begin{array}{l}\text { Sig. } \\
\text { F }\end{array}$ & B & $t$ & $\begin{array}{c}\text { Sig. } \\
\mathrm{t}\end{array}$ \\
\hline \multirow[t]{4}{*}{$\begin{array}{l}\text { Core } \\
\text { Competence }\end{array}$} & $\begin{array}{l}\text { Intensive } \\
\text { Training }\end{array}$ & \multirow[t]{4}{*}{$.488 a$} & \multirow[t]{4}{*}{.239} & \multirow[t]{4}{*}{27.016} & \multirow[t]{4}{*}{0.00} & 0.042 & 0.588 & 0.00 \\
\hline & $\begin{array}{l}\text { Quality } \\
\text { Assessment }\end{array}$ & & & & & -0.055 & -0.734 & .464 \\
\hline & Motivation & & & & & 0.570 & 9.601 & .000 \\
\hline & SPE & & & & & $\begin{array}{l}- \\
0.079\end{array}$ & -1.044 & .297 \\
\hline
\end{tabular}

\section{Conclusion}

In the oil and gas sector, the need for competent employees continues to be perceived. The implementation of competency-based models is a tool for developing competent workers. The methodology leverages the five primary factors influence the core competence as outlined by industrial literature and preliminary study that intensive training, quality assessment, are playing a significant role to achieve a successful competency model and competent employees. The study recommend examining the role of disciplinary action against employees who fails more than 3 times in final assessment and verification and recommend manpower development specialist to study the social status of individual failed employees

Furthermore, the current study defined the factors that render the competency model proficient in trainees' perspectives.

\section{References}

Abder, C. H., \& Thomas, B. D. (2003). Competency Systems-A Task Based Learning and Development Method. Paper presented at the SPE Latin American and Caribbean Petroleum Engineering Conference.

Abdullah, D., \& Suring, J. C. (2011). The relationship between motivation to transfer, training design, transfer climate and transfer of training. Paper presented at the International Conference on E-business, Management and Economics, Dubai, United Arab Emirates.

Al-Awai, S., Samir, O., \& Binthabet, H. A. (2002). ADMA-OPCO Operational Approach for Competency Assurance. Paper presented at the Abu Dhabi International Petroleum Exhibition and Conference.

Al-Awai S, S. O., Binthabet, H. A. (2002). ADMA-OPCO Operational Approach for Competency Assurance. Paper presented at the Abu Dhabi International Petroleum Exhibition and Conference.

Al-Marri, W., Al-Habaibeh, A., \& Watkins, M. (2018). An investigation into domestic energy consumption behaviour and public awareness of renewable energy in Qatar. Sustainable cities and society, 41, 639-646. doi: https://doi.org/10.1016/j.scs.2018.06.024

Al Matroushi, S. (2004). Development of a competent workforce for the oil and gas sector. Paper presented at the Abu Dhabi International Conference and Exhibition. 
Ali, M. M., Zhao, H., Li, Z., Ahmed, O., Alfasatleh, I., \& Maglas, N. N. (2020). The impact of the oil and gas industry on NORMs of groundwater and their annual effective dose in Ma'rib, central Yemen. Acta Geophysica, 68(5), 1421-1431. doi: doi:10.1007/s11600020-00482-5

Alipour, M., Salehi, M., \& Shahnavaz, A. (2009). A study of on the job training effectiveness: Empirical evidence of Iran. International journal of business and management, 4(11), 63-68.

Almatroushi, S. R. (2006). The Road to a Competent and Motivated Workforce. Paper presented at the Abu Dhabi International Petroleum Exhibition and Conference.

Alvarez, K., Salas, E., \& Garofano, C. M. (2004). An integrated model of training evaluation and effectiveness. Human resource development Review, 3(4), 385-416.

Anane, C. A. (2013). Competency based training: Quality delivery for technical and vocational education and training (TVET) institutions. Educational research international, 2(2), 117-127.

Andersen, S., \& Mostue, B. A. (2012). Risk analysis and risk management approaches applied to the petroleum industry and their applicability to IO concepts. Safety Science, 50(10), 2010-2019. doi: https://doi.org/10.1016/j.ssci.2011.07.016

Antariksa, Y. (2009). Managing Strategy, Career and Mindset: Salamadani Pustaka Semesta, Bandung.

Appelbaum, S. H., Louis, D., Makarenko, D., Saluja, J., Meleshko, O., \& Kulbashian, S. (2013). Participation in decision making: a case study of job satisfaction and commitment (part one). Industrial and commercial training.

Arneson, J., Rothwell, W. J., \& Naughton, J. (2013). Training and development competencies redefined to create competitive advantage. $T$ and $D, 67(1), 42-47$.

Aven, T. (2016). Ignoring scenarios in risk assessments: Understanding the issue and improving current practice. Reliability Engineering \& System Safety, 145, 215-220. doi: https://doi.org/10.1016/j.ress.2015.08.012

Bain, K., Landman, M., Frost, K., Raphael-Leff, J., \& Baradon, T. (2019). Lay counselors: thoughts on the crossing of ecological frameworks and the use of lay counselors in the scale up of early infant mental health interventions. Infant Mental Health Journal, 40(6), 889-905.

Blanchard, O. (2006). European unemployment: the evolution of facts and ideas. Economic policy, 21(45), 6-59.

Borch, O. J., \& Kjerstad, N. (2018). The offshore oil and gas operations in ice infested water: resource configuration and operational process management Sustainable shipping in a changing Arctic (pp. 401-425): Springer.

Bosch, G., \& Charest, J. (2009). Vocational training: international perspectives: Routledge.

Capp, F. W., Lazarewicz, M. L., \& Rojas, H. A. (2010). Methods and systems for intentionally isolating distributed power generation sources: Google Patents.

Connor, J. (2014). Evolution of the nature and application of competence in the learning and development of oil and gas industry personnel. Paper presented at the IPTC, International Petroleum Technology Conference, Kuala Lumpur, Malaysia, .

Connor, J., Mark, Casey, Karen, Eddon, . (2014). Evolution of the nature and application of competence in the learning and development of oil and gas industry personnel. Paper presented at the International Petroleum Technology Conference. 
Farr, J. L., Hofmann, D. A., \& Ringenbach, K. L. (1993). Goal orientation and action control theory: Implications for industrial and organizational psychology. International review of industrial and organizational psychology, 8(2), 193-232.

Fassihi, M. R. (2005). Competency-Based Training and Development. Paper presented at the SPE Annual Technical Conference and Exhibition.

Figgis, J., \& Standen, A. (2005). Training skilled workers: Lessons from the oil and gas industry (N. C. f. V. E. R. A. 311 Ed.): NCVER,National Centre for Vocational Education Research

https://ncver.edu.au/research-and-statistics/publications/all-publications/training-skilledworkers-lessons-from-the-oil-and-gas-industry.

Finegold, D., \& Soskice, D. (1988). The failure of training in Britain: analysis and prescription. Oxford review of economic policy, 4(3), 21-53.

Gegenfurtner, A. (2011). Motivation and transfer in professional training: A meta-analysis of the moderating effects of knowledge type, instruction, and assessment conditions. Educational Research Review, 6(3), 153-168.

Hashim, A. S., Ahmad, W. F. W., \& Rohiza, A. (2010). A study of design principles and requirements for the $m$-learning application development. Paper presented at the 2010 International Conference on User Science and Engineering (i-USEr).

Henley, A., Pinheiro, A., \& Daly, D. (2011). Implementing HES\&S training in the oil \& gas industry: a brief overview. Occupational health \& safety (Waco, Tex.), 80(7), 84, 87.

Holton III, E. F., Bates, R. A., \& Ruona, W. E. (2000). Development of a generalized learning transfer system inventory. Human Resource Development Quarterly, 11(4), 333-360.

Howland, J. L., \& Moore, J. L. (2002). Student perceptions as distance learners in Internetbased courses. Distance education, 23(2), 183-195. doi: https://doi.org/10.1080/0158791022000009196

James L. Farr, D. A. H., David A Hofmann, Kathleen L. Ringenbach. (1993). International Review of Industrial and Organizational Psycology. Researchgate, 8(University of North Carolina at Chapel Hill, university of Manchester Institute of Science and Technology,UK, John Wiley \& Sons), 24.

Jargons, B. (2018). Job Satisfaction. Retrieved Dec, 6, 2018.

Jarossová, M. A. (2018). Attitudes and selected buying behaviour of Slovak consumers related to functional foods-preliminary research. Towaroznawcze problemy jakości(1), 42-50.

Jones|, V. (2015). Tackling the Skills Shortage Challenge in the Oil, Gas Industry. Rigzone Staff/Friday; University of Houston Energy (UH Energy). Retrieved https://www.rigzone.com/news/oil_gas/a/138175/tackling_the_skills_shortage_chal lenge_in_the_oil_gas_industry/

Karami, M., Samimi, Amir, Ja'fari, Mahsa. (2020). Necessity to Study of Risk Management in Oil and Gas Industries (Case Study: Oil Projects). Progress in Chemical and Biochemical Research, 239-243. doi: 10.33945/SAMI/PCBR.2020.3.6

Kedzierski, B. A. (2016). Royal Dutch Shell's Journey to Strategic Competence Management. Journal of Petroleum Technology, 68(01), 46-51. doi: https://doi.org/10.2118/01160046-JPT

Koç, M. (2017). Learning analytics of student participation and achievement in online distance education: A structural equation modeling. Educational Sciences: Theory \& Practice, 17(6).

Lawler, E. E., Mohrman, Allan M, Resnick, Susan M. (1984). Performance appraisal revisited. Organizational dynamics, 13(1), , 20-35. doi: doi.org/10.1016/0090-2616(84)90029-9 
Lee, P., Allen, K., \& Daly, M. (2012). A 'Communication and Patient Safety'training programme for all healthcare staff: can it make a difference? BMJ Quality \& Safety, 21(1), 84-88.

Lee, S. H., \& Ming, J. A. (1999). Effective reaction evaluation in evaluating training programs. Purposes and dimension classification. Performance Improvement, 38(8), 32-39.

Leopold, T. A., Ratcheva, V., \& Zahidi, S. (2017). The future of jobs and skills in Middle East and North Africa: Preparing the region for fourth industrial revolution. World Economic Forum. Retrieved http://hdl.voced.edu.au/10707/438010.

Leuro, J., \& Kruger, T. (2014). Demonstrating the Competence of the Workforce. Paper presented at the IPTC 2014: International Petroleum Technology Conference.

Lo, K., Macky, K., \& Pio, E. (2015). The HR competency requirements for strategic and functional $\mathrm{HR}$ practitioners. The International Journal of Human Resource Management, 26(18), 2308-2328. doi: https://doi.org/10.1080/09585192.2015.1021827

Lucia, A. D., \& Lepsinger, R. (1999). Competency Models: Pinpointing critical success factors in organizations. San Francisco: lossey-Bass/Pfeffer.

Matteo, A. (2019). Use of Ontologies and Business Process Management Systems to Measure the "Knowledge Fit" of an Organisation. Budapesti Corvinus Egyetem.

McKinley, T., \& Huebner, C. (2018). Extractive Industries and Consumption Linkages to Enhance Industrialisation.

Naburi, E. G. (2014). RECRUITMENT PROCESS AND THE PERFORMANCE OF TANZANIA PETROLEUM DEVELOPMENT CORPORATION. mzumbe.

Noe, R. A., Hollenbeck, J. R., Gerhart, B., \& Wright, P. M. (2017a). Human resource management: Gaining a competitive advantage (5 ed.): McGraw-Hill Education New York, NY; https://tr1lib.org/book/5311179/322385.

Noe, R. A., Hollenbeck, J. R., Gerhart, B., \& Wright, P. M. (2017b). Human resource management: Gaining a competitive advantage: McGraw-Hill Education New York, NY.

Omar, S., Al Hosani, H., \& Moore, R. L. (2008). Information Technologies That Enable Human Competence Development and Assurance. Paper presented at the Intelligent Energy Conference and Exhibition.

Orser, N. A. (2001). An on-the-job training system at Alias PCB Technologies.

Perry, N. E., Phillips, Lynda, Hutchinson, Lynda. (2006). Mentoring student teachers to support self-regulated learning. The elementary school journal, 106(3), 237-254. doi: https://doi.org/10.1086/501485

Pignot-Shahov, V. (2012). Measuring L2 receptive and productive vocabulary knowledge. Language Studies Working Papers, 4(1), 37-45.

Pulakos, E. D., Mueller-Hanson, R. A., \& O'Leary, R. S. (2008). Performance management in the United States. Performance management systems: A global perspective, 97-114.

Rodríguez, C. M., \& Gregory, S. (2005). Qualitative study of transfer of training of student employees in a service industry. Journal of Hospitality \& Tourism Research, 29(1), 4266.

Rothwell, W. J., Arneson, J., \& Naughton, J. (2013). ASTD competency study: The training \& development profession redefined: American Society for Training and Development.

Rothwell, W. J., Graber, James M,Graber, Jim M. (2010). Competency-based training basics: American Society for Training and Development; https://www.td.org/. 
Rouiller, E. M., Capt, M., Dolivo, M., \& De Ribaupierre, F. (1989). Neuronal organization of the stapedius reflex pathways in the rat: a retrograde HRP and viral transneuronal tracing study. Brain Research, 476(1), 21-28.

Rouiller, J. Z., \& Goldstein, I. L. (1993). The relationship between organizational transfer climate and positive transfer of training. Human Resource Development Quarterly, 4(4), 377-390.

Rui, Z., Cui, K., Wang, X., Chun, J.-H., Li, Y., Zhang, Z., . . . Patil, S. (2018). A comprehensive investigation on performance of oil and gas development in Nigeria: technical and non-technical analyses. Energy, 158, 666-680.

Saadawi, H. N., \& Al Olama, S. (2005). Competency-based Program: An Effective Tool to Develop Graduate Engineers. Paper presented at the SPE Middle East Oil and Gas Show and Conference.

Saeed, R., Mussawar, S., Lodhi, R. N., Iqbal, A., Nayab, H. H., \& Yaseen, S. (2013). Factors affecting the performance of employees at work place in the banking sector of Pakistan. Middle-East Journal of Scientific Research, 17(9), 1200-1208.

Sahinidis, A. G., \& Bouris, J. (2008). Employee perceived training effectiveness relationship to employee attitudes. Journal of European Industrial Training.

Schmidt, S. W. (2007). The relationship between satisfaction with workplace training and overall job satisfaction. Human Resource Development Quarterly, 18(4), 481-498.

Sugarindra, I., Suryoputro, M. R., \& Novitasari, A. T. (2017). Hazard identification and risk assessment of health and safety approach JSA (Job Safety Analysis) in Plantation Company. Paper presented at the IOP Conf. Ser. Mater. Sci. Eng.

Taber, M. J., \& McGarr, G. W. (2013). Confidence in future helicopter underwater egress performance: An examination of training standards. Safety Science, 60, 169-175. doi: https://doi.org/10.1016/j.ssci.2013.07.023

Tarrant, C., Angell, E., Baker, R., Boulton, M., Freeman, G., Wilkie, P., . . Ketley, D. (2014). Responsiveness of primary care services: development of a patient-report measurequalitative study and initial quantitative pilot testing.

Rueda, T. Y. (2006). Developing pragmatic competence in a foreign language. Colombian applied linguistics journal(8), 169-182.

Van Haitsma, T. A., Gonzalez, S. P., Swider, N. S., De Laura, A., Salinas, T., Costa, D., \& McGough, S. (2018). Effects of Mental Strength and Mindfulness Training on Exercise Performance: 1361 Board\# 169 May 31900 AM-1030 AM. Medicine \& Science in Sports \& Exercise, 50(5S), 326-327.

Vathanophas, V. (2007). Competency requirements for effective job performance in Thai public sector. Contemporary management research, 3(1), 45-45.

Vathanophas, V., \& Liang, S. Y. (2007). Enhancing information sharing in group support systems (GSS). Computers in Human Behavior, 23(3), 1675-1691.

Walker, P. D., Cammy, N. E., Ellis, B. J., \& Seibert, K. D. (2011). Operations skills for the 21st century. Paper presented at the National Petrochemical \& Refiners Association (NPRA) Annual Meeting, Paper AM-11-68.

Wang, Y. (2018). Investment analysis project for Petrofac Ltd.

Warner, R. J. (2009). A comparison of teaching models that promote academic achievement in an inclusive secondary classroom: Tarleton State University.

Warwick, C. (2014). How international medical graduates view their learning needs for UK GP training. Education for Primary Care, 25(2), 84-90. 
Williams, S., \& Turnbull, S. (2015). Developing the next generation of globally responsible leaders: Generation $Y$ perspectives and the implications for green HRD. Advances in Developing Human Resources, 17(4), 504-521.

Wilson, C. (2015). Designing the purposeful organization: how to inspire business performance beyond boundaries: Kogan Page Publishers.

WorldBank. (2015). Republic of Yemen : Unlocking the Potential for Economic Growth cb. http://hdl.handle.net/10986/23660. Retrieved "World Bank. 2015. Republic of Yemen : Unlocking the Potential for Economic Growth. World Bank, Washington, DC. (C) World Bank. https://openknowledge.worldbank.org/handle/10986/23660 License: CC BY 3.0 IGO."

Xiao, J. (1996). The relationship between organizational factors and the transfer of training in the electronics industry in Shenzhen, China. Human Resource Development Quarterly, 7(1), 55-73.

Yasin, S., \& Ali, Z. (2016). Examining the competency mapping interventions impact on enhancing role efficacy. International Journal of Academic Research in Accounting, Finance and Management Sciences, 6(4), 226-233. 